\title{
Government E-Service Delivery in Rural Bangladesh: A Public- Private Partnership Approach
}

\author{
Shah Md Safiul Hoque ${ }^{1}$ K. M. Mahiuddin² Abdullah Al Muneem ${ }^{3 *}$ \\ 1. Faculty of Business, Sohar University, Al Jameah Street, Sohar 311, The Sultanate of Oman \\ 2. Department of Government and Politics, Jahangirnagar University, Savar, Dhaka 1342, Bangladesh \\ 3. Department of Tourism and Hospitality Management, Faculty of Business Studies, University of Dhaka, \\ Dhaka 1000, Bangladesh
}

\begin{abstract}
This paper reviews and analyzes government e-service delivery through Union Digital Centers (UDCs), being identified as telecenters. With the emergence of e-governance, e-services delivery has become expedited across different countries in the world including Bangladesh to foster socio-economic development. However, the concept of 'digital divide' or 'digital gap' limits the ultimate success of e-delivery services by increasing the gap between rich and poor. In connection to the digital gap, literature evidence that telecenters have largely failed to reach targeted hardcore poor. This research has used a survey technique to collect data from 383 respondents located at 14 different UDCs and seven divisions. The findings of the paper contemplate a positive response in terms of availability, cost, convenience, and delivery of services. Nevertheless, strengthening the approach of Public-Private Partnerships (PPP) remains a necessity to reach the success goal in e-governance. This study would be particularly helpful for practitioners or government policy-making agencies to identify perceptions on e-services at root level.
\end{abstract}

Keywords: telecenters, e-governance, e-service delivery, socio-economic development, public-private partnership, Bangladesh

DOI: $10.7176 / \mathrm{EJBM} / 11-2-12$

\section{Introduction}

The global tools of Information and Communication Technology (ICT) have impacted our life in terms of carrying out personal and social communication and networking. In the realm of government institutions, ICTs are being used for managing big data, internal and external communication, fostering political environment of public transparency and accountability, and easy reach out of citizens with its services. ICT empowers civil society to play its role more effectively and facilitates the performance of governments' main functions of serving the people (Misnikov, 2003). With this regard, government institutions attempting continued progress in building ICT infrastructure and making steps to add the popular services of Internet or Internet of Thing (IoT). To improve public sectors' business processes and taking public services closest to the doorstep of people the use of e-governance and e-service delivery system are key terminologies being used in the ICT literature. Calista and Melitski (2007) have identified e-governance as an interactive system by which governments interact democratically with citizens. Correspondingly, it is argued that e-governance promotes transparency, participation, and more government accountability to citizens through greater public access to information. Within an e-governance system, e-service delivery has nowadays become a common trend in all countries regardless of its socio-economic standards.

When an e-governance system fails to function effectively, it arises the concept of 'digital gap' or 'digital divide'. Digital gap or 'social exclusion' is generally understood as determining the disparities in ICTs access and countrywide everyday use of ICTs to meet livelihoods information for better social and economic opportunities. In some cases, digital gap can be promoted by an uneven distribution of computer access and skills biases (Bélanger and Carter, 2006). Similarly, it can also be observed in connection with the ability of a government referred to make their online services equally accessible and beneficial (Warschauer, 2004). Cullen (2003) describes the digital divide as 'the gap that exists in most countries between those with ready access to the tools, information and communication technologies (ICTs), and those without such access or skills. This is particularly identifiable in reference to a developing country such as Bangladesh, where still a large number of people living below the poverty line. In general, four interpretations of digital divide are noticeable including gap in access to use of ICTs, gap in the ability to use ICTs, gap in actual use, and gap in the impact of use (Fink and Kenny, 2003). To minimize the digital gap or digital divide, the use of multilevel telecenters has received significant 
attention in delivering e-services at a very root level (van Dijk and Hacker, 2003; Warschauer, 2004).

Following the worldwide trend toward the use of telecentres, Bangladesh has established telecentres called Union Digital Centers (UDCs) at the grassroots to safeguard rural community from being excluded and reduce the digital gap between urban and rural communities. There now exists a UDC in each Union Parishad (Council), the lowest unit of local government. The primary objectives are to meet the needs of access to ICT devices and internet, access to computer literacy skills training, access to information and services thereby having improved social and economic standard of living of the rural community. This paper examines the characteristics of the UDC and its users, and explores the perceptions of the service receivers to identify if UDCs are playing any significant role in reducing digital gap in rural Bangladesh. In so doing, several issues have been explored including availability of services at UDCs, cost of services, convenience in availing services at UDC, and quality of service rendered at UDC.

\section{E-governance, Telecenters, and Public-Private Partnerships}

Calista and Melitsk (2007) have mentioned that e-governance deal with changing the manner by which governments interact democratically with citizens. It is argued that e-governance promotes transparency, participation, and more government accountability to citizens through greater public access to information. The most important anticipated benefits of e-government include improved efficiency, convenience, and better accessibility of public services. Governments at different levels worldwide are under pressure to deliver public services more efficiently at lower cost and less time. As e-governance service has grown, it has created a major challenge for itself which is identified as 'digital divide'. Digital gap exists between urban and rural areas, between the rich and the poor, between male and female; and due to the spread of digitization in private and public spheres in Bangladesh, this gap might further widen and subsequently hinder the adoption of egovernance system and delivery of e-services (Baqir, Palvia, and Latif, 2007).

One way to overcome these challenges is to introduce shared multipurpose telecenters on a public-private partnership basis. The term partnership is seen as cooperation (Langford and Roy 2006; Hodge and Greve, 2009), joint venture (Skelcher 2007), interplay (Gómez-Barroso and Feijóo 2010), strategic alliance (Hancox and Hackney 1999), and collaboration (Donahue, 2010). According to Knowledge Lab (2018), a PPP is "a long-term contract between a private party and a government entity for providing a public asset or service, in which the private party bears significant risk and management responsibility, and remuneration is linked to performance". Forrer, Kee, Newcomer, and Boyer (2010) define PPP as an agreement between government and private agencies in which the private agency plays a role in taking risk and decision-making; Savas (2000) has defined PPP as a plan between a government and a private entity which they mutually carryout as a public initiative. However, Maskin and Tirole (2008) argued that PPP involves a continuing cooperation where the cohorts share risks, resources, goals, and combine the strengths of both sectors. In this study, we define PPP as an understanding and agreement on the business contract between public and private entities where they jointly play roles to chase a public interest with shared risks and opportunities.

According to Marschollek et al. (2010), since the early 1990s PPPs in ICT-driven innovative services have started to gain acceptance. Claps (2012) has mentioned that the rate of PPP adoption in government-initiated IT projects is expected to increase in the future. PPPs in ICT-driven public service delivery would not only be more cost effective for the government agencies but citizens could also gain advantages of availing quality services in a shorter time, lower cost, and decreased corruption, which would certainly increase satisfaction of the citizens over a public administration system. $\mathrm{Ng}$, Wong, and Wong (2010) also claimed that the success of a PPP project is dependent upon the satisfaction of concerned stakeholders to attain outcomes. They also suggested six performance indicators for satisfaction of the concerned stakeholders and success of the PPP such as i) prompt, stable, and reliable service delivery, ii) reasonable cost of service, iii) meeting output requirements specified in contract, iv) fair, open, and transparent procurement procedures, v) level playing field in the market, and iv) efficient channel of communication between the community and service provider.

At present, telecenters are being used as a common model in different least or middle-income countries to offer grassroots people as a means to access to ICTs and its' services, especially to those who have no ICT facilities at home, and/or who lack ICT skills and information literacy. Several scholars have explored the reasons underlying the popularity of the idea of telecenter; it is seen as an effective tool for reducing the wide digital divide that exists between urban and rural areas and between the rich and the poor. According to (McConnell, 2001), telecenters have gained prominence as a primary instrument of bringing the benefits of ICTs to poor communities where the technological infrastructure is inadequate and the costs of individual access to these 
technologies are relatively high. The centers also provide opportunities for access to information by overcoming the barriers of distance and location, and by facilitating this access to information and communication, they were also able to foster social cohesion and interaction Young, Ridley, and Ridley, 2001). Similarly, Dixit (2009: 281) has argued that the telecenters provide opportunities to improve communication and reconnect citizens to the state offering greater access to information and group-based discussion.

\section{Development of Telecenter in Bangladesh}

The telecenter movement in Bangladesh was started in the late 1980s. A non-governmental organization, Dhaka Ahsania Mission established the first community-learning center in 1987. The center was locally known as Gonokendra (Public-center) for providing facilities to read newspapers, exchange experiences, learn from success stories, and get information about innovations to improve livelihoods. Gonokendra mainly used hard copy materials as only 5\% of them had computers and there was no internet connectivity. Eventually they established more than 100 Gonokendras across the country. By 2001, many non-governmental organizations started establishing telecentres. For example, Katalyst envisages promoting commercially sustainable rural ICT initiatives in Bangladesh and piloted an entrepreneurship-driven model in partnership with two private sector players for establishing Rural ICT Center (RIC) branded as Alokito Gram (Enlightened Village) and GHAT. Similarly, Practical Action Bangladesh established two Rural Technology Centers (RTC) in 2006 for contributing toward poverty reduction. In the telecom sector in Bangladesh, launching of GSM based internet connectivity (GPRS, EDGE) played a noteworthy role in boosting telecentres across the country.

Bureaucratic administrative process, resistance to change by civil service, centralization of government offices, and bribery as part of corruption irritated Bangladeshi citizens in their attempt to gain public services and information. This kind of situation has not only been discouraging millions from accessing public services but also been preventing overall development in terms of wasted resources at both government institutions and citizen level. The situation is even worse for the rural people as they are comparatively poor, less educated and less empowered. In addition, the rural communities in Bangladesh are required to travel to the district or subdistrict administrator's office which is about 10-40 km away respectively from their residence. However, the centralized bureaucratic process and long-distance travelling drive rural people to engage a market intermediary or a person who holds special access to public offices to avail their required information and services. The whole picture results in a high degree of inequitable participation in market opportunities and in decision-making processes.

To illustrate, getting hold of one's land record is a cumbersome and lethargic process which requires spending of long hours at the district administrator's office and hard worked earnings for travelling and paying middleman or giving bribes to government offices. Another example is the low-skilled workers seeking overseas employment who are major contributors to the Bangladesh economy (annual remittance inflow of USD 10 billion). They need to pay up to ten times the official fee for their paperwork because of financial exploitation by unscrupulous recruitment agents. A final example, demonstrating inequitable participation is the inability of poor sugarcane farmers in availing of the 'purjee' (paper-order) from state-owned sugar mills timely. These farmers are greatly dependent upon market intermediaries for getting the right information at the right time regarding public enterprise procurement of sugarcane. The outcome perpetuates an unpredictable service delivery system which consumes significant time, eats up the earnings of the rural poor and increases their dependence on middlemen in order to reduce their number of visits to public offices at the district headquarter and sub-district levels.

As a result of such settings in the public sectors, experiences gathered from local and global telecenters, recommendations from international development agencies, and political manifestos of present government egovernance and e-services delivery were adopted in Bangladesh. Adoption of e-governance systems and delivering public services at rural areas especially through UDCs is a part of Bangladesh vision 2021. In 2007, two Community e-Centres (CeCs) were established as pilots in association with UNDP USAID and other local strategic partners to provide information and government services to rural people (Mahiuddin and Hoque, 2013). In early 2008, CeC was included as a driver project supported by Access to Information (A2I) program at Prime Minister's office (see http://www.a2i.pmo.gov.bd). A2I started with $30 \mathrm{CeCs}$ at the Union Parishad level. Later, CeCs were renamed as Union Information Service Centers (UISCs) and LGD gradually established UISCs in all Union Parishads of Bangladesh. In August 2014, the UISCs were again renamed as Union Digital Centers (UDCs); these have now become full blown multipurpose-telecentres and provide a unique example of publicprivate-partnership (PPP) in technology diffusion. 


\section{Structure and Functions of Union Digital Centers}

There are approximately 4,537 Union Digital Centers (UDCs) in Bangladesh; these are located at UP complexes across the country. These digital centers, which are being operated and managed on the basis of Public Private Partnership (PPP), provide approximately 102 services in rural areas of the country. Each UDC is operated by two local entrepreneurs, one of whom must be a female. A typical UDC is operated and managed by two local entrepreneurs of whom one must be a female. These entrepreneurs are selected by the Union Parishad (UP) Chairperson and Upazila Nirbahi Officer (sub-district executive officer) on the basis of their IT skills and capacity/interest to invest and run the center. UP provides space and utility to set up the center. Local Government Department (LGD) provides equipment required at the initial stage but the entrepreneurs are responsible for bearing the operating costs and further investment required to maintain existing equipment, to buy new equipment to deliver required services and increase their earnings. Entrepreneurs are not responsible to carryout UP jobs as they are not employees of the UP rather, they are the partners of the initiative of e-service delivery at the private-end. However, a UDC is located within a UP complex and entrepreneurs are supervised and monitored by the respective Chairperson of UP. Figure 1 below exhibits the structure of the UDC within the UP.

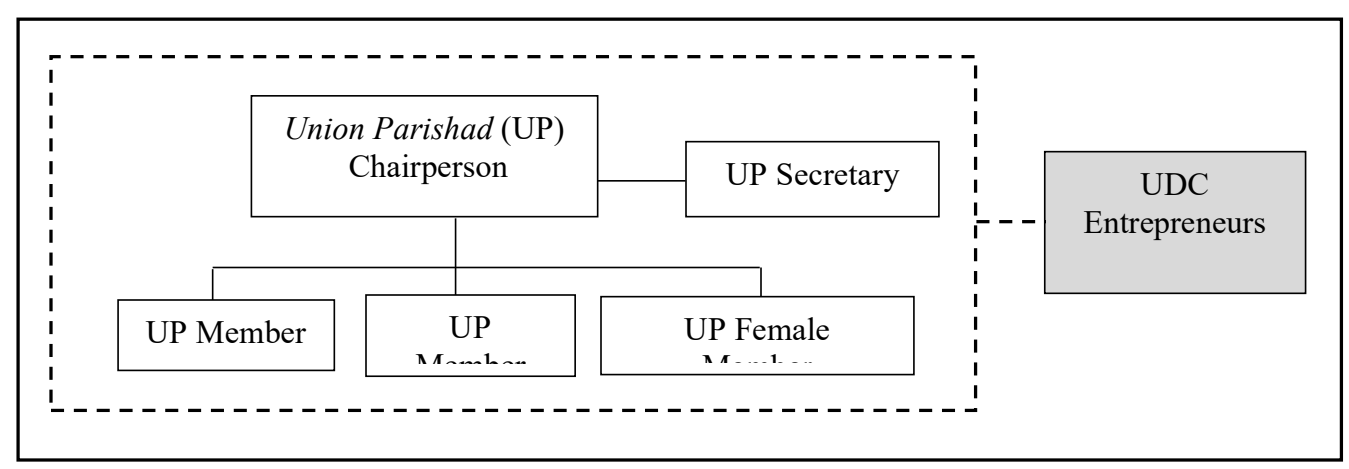

Figure 1. UDC Entrepreneurs at Union Parishad

The basic equipment set at each UDC includes: a desktop computer, laptop computer, printer, scanner, digital camera, mobile phone with wireless modem, photocopier, laminating machine, and multimedia projector, Uninterruptible Power Supplies (UPS) were provided along with solar panels where electricity was not available. Observation showed that the desktop computer, laptop, printer, scanner, digital camera, mobile phone with modem and UPS were available at $100 \%$ of UDC sites. However, the projector, photocopier and laminating machine were not seen at the majority of sites. Operators claimed that they have all the equipment of core necessity except multimedia projector. It was also stated that some of the equipment was not available and was currently being repaired.

Power supply found unreliable, particularly in rural areas. The supply may often be interrupted or disconnected, several UDC sites had solar systems for backup. All of the centers were seen to have UPS adapters to regulate the power supply but a large number of them were found not functioning. 100\% UDCs were reliant upon wireless modems for internet connectivity. Operators commented that data speeds via the wireless modem were not fast enough and that the speed needed to be increased. There are current plans to install optical fiber network at Union level and UDCs are expected to connect to broadband internet in the next one to two years.

UDC services are categorized into two groups: government services and commercial Services (Table 1). Provision of government services is seen to be much more focused but commercial services as well pursued by the users. To facilitate and strengthen the capacity to deliver services, UDCs have formed strategic partnerships with various organizations to offer extended services to mass people. These include: Dutch Bangla Bank, Mercantile Bank, Trust Bank Limited, One Bank Limited, Bkash Ltd, BRAC, Jibonbima (life insurance), Robi and Banglalink (mobile operators), Dhaka Ahsania Mission and Practical Action (NGOs), Bangladesh Computer Council, Infrastructure Development Company Limited (solar energy organization), and Cyber Cafe Owners' Association of Bangladesh (CCOAB), Ankur, Practical Action, Bangladesh Computer Samity (BCS), and Technology Today (Technology related news). 
Table 1. Key services offered at UDC

$\begin{array}{ll}\text { Government Service } & \text { Commercial Service } \\ \text { Education / Admission / exam results } & \text { Typing / Data Entry } \\ \text { Government forms download } & \text { Printing \& Photocopying } \\ \text { Birth and death registration } & \text { E-mail and Internet browsing } \\ \text { Overseas employment } & \text { CV and Job application } \\ \text { Passport / TIN (tax) certificate } & \text { ICT / English training } \\ \text { Health } & \text { Phone / Video conferencing } \\ \text { Livelihood information } & \text { Mobile Banking / Bank statement } \\ \text { Land } & \text { Scanning \& Laminating } \\ \text { VGD/VGF card database } & \text { Photography } \\ \text { Agricultural Information } & \text { Online visa application/visa form }\end{array}$

A2I has claimed that 4,547 UDCs have provided a total of 200 million services out of the 102 different types of services are available to offer. 3.2 million people visit UDCs per month to seek different kinds of services. A2I reports that between 2010 and 2014, UDCs have completed service transactions of 75 million birth registrations; 33.4 million m-banking (mobile-baking) transactions; 2.7 million life insurance applications; 2 million registrations for overseas employment; 0.45 million land records; provided 35,000 telemedicine; and computer literacy training sessions to 45,000 rural people who belong to relatively disadvantaged clusters. The pricing structure of some of the selected services offered at UDCs is presented in Table 2.

Table 2. Pricing Structure of Selected Services at UDCs

\begin{tabular}{|l|c|l|c|}
\hline Government Service & Price (BDT) & Commercial Service & Price (BDT) \\
\hline Online Birth registration & 50 & Document composition & 30 \\
\hline Online passport application & 50 & Document printing & 20 \\
\hline Online Hajj registration & 50 & E-mailing & 50 \\
\hline Online overseas employment registration & 50 & Internet browsing for specific items & 50 \\
\hline Agriculture/Education/Health related e-service & 50 & Video conference/call & 100 \\
\hline Information service & 10 & Multimedia projector rental & 200 \\
\hline $\begin{array}{l}\text { Online application for school/college/university } \\
\text { admission }\end{array}$ & 100 & Scanning & 30 \\
\hline Public examinations results & 30 & Visa check & 100 \\
\hline Government form download and print & 50 & Online job application & 100 \\
\hline
\end{tabular}

*BDT. 1 = US\$ 0.0131

The mode of service delivery at the outlets includes both online and offline activities. A service seeker needs to visit the center physically regardless of the mode of service delivery. A representative on behalf of the actual service seeker can seek the service where physical presence of actual service seeker is not mandatory. As a result, the majority of people in rural areas perceive that availing of services at the UDCs have significantly reduced the time and money required in comparison to the same services provided at remote district or sub-district headquarters in a traditional manner.

\section{Methodology}

This research has been approached by both quantitative and qualitative methods. The researchers have conducted an opinion-based research survey, in which a total of 383 respondents were consulted from randomly picked 14 UDCs being situated 7 divisions of Bangladesh. Apart from survey, extensive site observations also found very effective to interpret findings of this research. In order to analyze the data descriptive statistics, document analysis, and thematic content analysis techniques have been followed.

\section{Findings and Discussions}

The survey on 14 scientifically selected UDCs belonging to 7 divisions of the country revealed demographic attributes of UDC visitors using structured questionnaires. The majority of visitors at UDC are male (81\%) while the proportion of female visitors is much lower (19\%), the ratio of male and female is 51.04:48.6 out of the total projected population in the country. Most of the visitors are in the 16-25 age group (40\%) closely followed by the 26-40 age group (30\%). In terms of education, $14 \%$ have never been to school, $44 \%$ attended school level 
education in the class range of $1-10$, and $42 \%$ attended college level education in the class range of 11-16. As per occupation $37 \%$ are self-employed (farming and micro business), $30 \%$ are students, $11 \%$ are service holders, $10 \%$ housewives, $10 \%$ unemployed, and $2 \%$ in other occupations. Income generation for rural people is always more challenging. About $44 \%$ of UDC visitors claimed that they did not have any income, $27 \%$ stated that their monthly income was less than BDT.10000, 16\% of visitors' income was less than BDT.5000 and only $13 \%$ had monthly income more than BDT 20000 . The findings show that $55 \%$ of respondents did not have any knowledge about computers and the Internet, $31 \%$ had very little knowledge and skills and only $14 \%$ had knowledge and skills in operating computers and the Internet.

As mentioned earlier, UDCs offer a variety of services related to public and private organizations to rural people using ICTs. The key focus of UDC, however, is to provide government information and e-services. In terms of accessing government services the study found that $20.1 \%$ visitors requested agriculture and land related services; $21.1 \%$ pursued education related activities; $9.9 \%$ health related services; $13 \%$ local government related services; $4.5 \%$ employment related services; $11.2 \%$ passport related issues; $20.2 \%$ other services. It is notable that the government services they availed in the mentioned areas include seeking relevant information, downloading relevant forms or documents, on-line form submission; viewing or printing query results etc. Different categories of people access internet for varying purposes. This study reveals that-

a) Students seek access to online result publication, admission form completion, getting information about different schools, colleges, and universities;

b) Farmers and land owners seek access to information related to agriculture, productivity, and markets, in addition they also seek land record related services;

c) Local male and female youth seek access services related to application for passports and also registration for overseas employment opportunities which allows them to save valuable working time and money by reducing the number of visits to offices very far away from their locality;

d) Local people regardless of gender, age, and occupation seek local government related services like birth registration, death registration, and social benefits etc.

To accomplish such activities rural people would have to spend more time and money and unwanted aggravation if there were no provision of digital delivery of services. Moreover, the demographic attributes of rural people and type of information and services they seek at UDC provide evidence of their importance. But the key question is how visitors measure the services provided by the UDCs and its entrepreneurs. Hence, we analyzed the views of rural people visiting UDC for accessing services and focused upon the availability, cost, convenience, and quality of rendering services. Empirical data collected from fourteen UDCs are analyzed to assess satisfaction level of users on e-services they received through UDCs in terms of availability of services, cost of services, convenience of services and finally service rendering quality. In total, $12.8 \%$ of users strongly agree and $55.1 \%$ users agree that they are satisfied with overall availability of services through UDCs while $8.6 \%$ of users strongly agree and $50.1 \%$ agree that they are satisfied with overall cost for services received through UDCs. About $15.7 \%$ respondents strongly agree and $48.8 \%$ agree that they are satisfied with overall convenience of services received through UDCs. In terms of service rendering quality of UDCs, $13.1 \%$ strongly agree and $44.9 \%$ agree that they satisfied. It is found that slightly less than $40 \%$ of the users have doubts about services quality through UDCs, which need to be addressed with priority for sustainability of UDCs. By focusing on these elements, we measure the overall satisfaction level of e-services provided by the targeted UDCs. In this regard we used a five points scale to frame the opinion from respondents. The used scale is leveled as $1=$ strongly disagree, $2=$ disagree, $3=$ moderately agree, $4=$ agree, and $5=$ strongly agree. Table 3 has shown a summarized view of overall satisfaction of the respondents in this research reflecting e-services delivery perception.

Table 3. Visitors' views on overall satisfaction from e-services at UDC $(n=383)$

\begin{tabular}{|l|l|l|l|l|l|l|}
\cline { 2 - 7 } \multicolumn{1}{c|}{} & $\begin{array}{l}\text { Strongly } \\
\text { Disagree }\end{array}$ & Disagree & $\begin{array}{l}\text { Moderately } \\
\text { Agree }\end{array}$ & Agree & $\begin{array}{l}\text { Strongly } \\
\text { Agree }\end{array}$ & Total \\
\hline $\begin{array}{l}\text { Overall Satisfaction } \\
\text { on UDC }\end{array}$ & 10 & 43 & 137 & 149 & 44 & 383 \\
\cline { 2 - 7 } & $2.6 \%$ & $11.2 \%$ & $35.8 \%$ & $38.9 \%$ & $11.5 \%$ & $100 \%$ \\
\hline Total Responses & 116 & 384 & 2241 & 3085 & 1068 & 6894 \\
\hline Percentage & $1.68 \%$ & $5.57 \%$ & $32.50 \%$ & $44.74 \%$ & $15.49 \%$ & $100 \%$ \\
\hline
\end{tabular}

Overall user satisfaction on receiving services through UDC is analyzed and shown in table 5.5 above. Among the 383 respondents 10 respondents, which are $2.6 \%$ of the total respondents strongly disagree on "overall 
Satisfaction about UDC" which is the lowest response. While 149 respondents, which are $38.9 \%$ of the total respondents, agree that they are satisfied with the overall performance of UDC so far. This is the found to be the highest response. Apart from these, Table 4 has exhibited descriptive statistics for overall satisfaction level

Table 4. Summary of descriptive statistics

\begin{tabular}{|l|r|}
\hline Mean & 3.45 \\
\hline Standard error mean & 0.047 \\
\hline Median & 4 \\
\hline Mode & 4 \\
\hline Standard deviation & 0.928 \\
\hline Variance & 0.861 \\
\hline Range & 4 \\
\hline Min & 1 \\
\hline Max & 5 \\
\hline Percentiles $25 \%$ & 3 \\
\hline $50 \%$ & 4 \\
\hline $75 \%$ & 4 \\
\hline
\end{tabular}

Here, the respondent number is $n=383$ and the average "overall satisfaction about UDC" is more than 3 or specifically 3.45. If we arrange the data set in ascending order the midpoint will be 4 that indicates $38.90 \%$ respondents agree with the overall satisfaction about UDCs. The mode value 4 , which denotes that $51.6 \%$ respondents did satisfy with the services of UDCs. Standard deviation is 0.928 indicating the users agreed satisfaction levels on the overall satisfaction about UDC is ranging from 2.52 to 4.38. The highest value is 5 and lowest value is 1 while the Range is 4 . As per percentile, $1^{\text {st }} 25 \%$ is 3 that means when we arrange the data in ascending order then we find 96 respondents say that they are moderately satisfied with overall performance of UDCs; $2^{\text {nd }} 25 \%$ ) is 4 that means 96 respondents agree; and $3^{\text {rd }} 25 \%$ is 4 , which interprets 96 respondents agree with the overall satisfaction about UDC. In general, the overall findings revealed that most of the visitors 'moderately agree' or 'agree' on the issues they were asked to respond to, which is a positive perception.

UDCs are established to take public services closer to the rural community and the entrepreneurs on PPP basis. Therefore, national facilitators need to identify more services needed for the community with active participation of community people and entrepreneurs. National facilitators need to monitor effectively if community people are over charged for services and entrepreneurs are maintaining UDC office hours and keeping required equipment available and functional. To ensure users' satisfaction on services through UDCs more training are needed for the entrepreneurs in the area of entrepreneurship, service and customer relationship management, and technical skills enhancement to prepare them as dedicated entrepreneurs of UDCs. In this particular situation, feedback, suggestion, or desire of the rural community on the type of information and services they seek, price they are paying for services, entrepreneurs and UP members' attitudes should be recorded on regular basis using a communication channel and measures should be taken accordingly. At the same time, nationwide awareness and promotional activity should be taken about e-services availability through UDCs and make rural community understand of why they should avail and patronize the e-service delivery system.

In the context of e-service delivery in Bangladesh, UDC has set a unique example of PPP in countrywide delivery of ICT-enabled government and commercial services. These digital centers are expected to be sustainable due to the involvement of local entrepreneurs as primary stakeholders. The PPP approach helps in reducing risks and operating costs at the government level and in generating new opportunities for the rural citizens in terms of effective access to information and government services at not only reduced cost and time but also in an environment of increased transparency and reduced corruptions. Moreover, establishment of UDCs opened up opportunities for the rural youth to reveal themselves as ICT related service providing entrepreneurs in rural Bangladesh. It is noteworthy that within a short term the UDC initiatives have created 9,094 entrepreneurs who are local youths residing in 4,547 UPs (two entrepreneurs in each UDC). Out of these, 50\% i.e., 4,547 entrepreneurs are women which is a landmark considering that the PPP approach opened up opportunity for rural women to be involved in entrepreneurship activities.

According to the Bangladesh Bureau of Statistics (2014) UDC Survey, UDCs earn about BDT. 41.65 million (Approx. US\$ 0.545 million) per month and spend about BDT. 17.34 million (Approx. US\$ 0.227 million) demonstrating a collective profit of BDT. 24.31 million (Approx. US\$ 0.319 million) per month, which highlights financial sustainability for UDCs, although they are still in their infancy. However, it is expected that 
the concerned entrepreneurs will strive to identify and introduce new services beneficial to the rural communities and thereby generate additional revenues and earn additional profits. Since the entrepreneurs are entitled to keep all of the earned profits they will be more likely to exhibit entrepreneurial attitudes to the visitors and strive to deliver quality services in terms of availability, cost, time, and response to visitors' queries. However, while entrepreneurs attempt to provide quality services they will also have to ensure the functionality of the equipment used for service delivery by carrying out regular equipment services and buying new potential equipment to offer efficient services to visitors.

\section{Conclusion}

Public Private Partnership model of UDC is the more practical option for adopting government e-service delivery and taking its benefits to the grassroots considering the existing issues of digital divide as well as the common socio-economic challenges of Bangladesh. However, in consideration to the long-term sustainability of UDCs, essential measures should be encountered for effective functionality of the centers along with enough motivational opportunities for the entrepreneurs. Although the visitors do not have adverse opinion on the UDC and the services delivered so far, they do not as well agree that the services they receive are pleasing enough in terms of availability, cost, convenience, and delivery of services. Moreover, the rural people do not confidently perceive that access to information and public services through UDC contribute to their socio-economic status. As a result, the present scenario of e-service delivery in rural areas through UDCs, strongly suggest further improvement in offering need based innovative services at a lesser cost and in more convenient ways. Necessary attempts are also inevitable to improve the environment of UDC and transfer the skills essentials for the entrepreneurs related to ICT-based micro enterprise operation in rural Bangladesh.

\section{References}

Bangladesh Bureau of Statistics. (2014). Statistical Pocket Book 2014, Dhaka: Ministry of Planning.

Baqir, M., Palvia, P. \& Latif, A. (2007). Antecedents of e-Government success: A phenomenological Study. In Proceedings of the American Conference on Information Systems.

Calista, D. J., \& Melitski, J. (2007). E-government and e-governance: Converging constructs of sector information and communications technologies. Public Administration Quarterly, 31(1/2), pp. 87-120.

Carter L., \& Bélanger F. (2006). The Effects of the Digital Divide on E-Government: An Emperical Evaluation. Proceedings of the 39th Annual Hawaii International Conference on System Sciences (HICSS'06), Kauai, Hawaii, 2006, pp. 81c. doi:10.1109/HICSS.2006.464

Claps, M. (2012). The Do's and Don'ts of Public-Private Partnerships. Gartner, 10 February, G00229098.

Cullen, R. (2003). The digital divide: A global and national call to action. The Electronic Library, 21(3), 247257, https://doi.org/10.1108/02640470310480506

Dixit, V. (2009). Telecentres: The new public spheres?. In G. Sahu, Y. Dwivedi, \& V. Weerakkody (Eds.), E-Government Development and Diffusion: Inhibitors and Facilitators of Digital Democracy (pp. 281-298). Hershey, PA: IGI Global. doi:10.4018/978-1-60566-713-3.ch016

Donahue, J. D. (2010). The race: Can collaboration outrun rivalry between American business and government? Public Administration Review, 70(Special Issue), S151-S152.

Fink, C. \& Kenny, C., J. (2003). W(h)ither the digital divide? Info, 5(6), 15-24, https://doi.org/10.1108/14636690310507180

Forrer, J., Kee, J.E., Newcomer, K.E. \& Boyer, E. (2010). Public-private partnerships and the public accountability question. Public Administration Review, 70(3), 475-484.

Gómez-Barroso, J., L. \& Feijóo, C. (2010). A conceptual framework for public-private interplay in the telecommunications sector. Telecommunications Policy, 34(9), 487-495.

Greve, C. (2015). Ideas in Public Management Reform for the 2010s: Digitalization, Value Creation and Involvement. Public Organization Review, 15(1), 49-65. https://doi.org/10.1007/s11115-013-0253-8

Hancox, M. \& Hackney, R. (1999). Information technology outsourcing: Conceptualizing practice in the public and private sector aims of the research context of the research. In Proceedings of the $32^{\text {nd }}$ Annual Hawaii International Conference on System Sciences.

Hodge, G., A. \& Greve, C. (2009). PPPs: The passage of time permits a sober reflection. Economic Affairs, 3339.

Knowledge Lab. (2018, March 20), What is a PPP: Defining "Public-Private Partnership". Retrieved from https://pppknowledgelab.org/guide/sections/3-what-is-a-ppp-defining-public-private-partnership

Langford, J. \& Roy, J. (2006). E-government and public-private partnership in Canada: When failure is no longer an option. International Journal of Electronic Business, 4(2), 118-135. 
Mahiuddin, K., M. \& Hoque, S., M. (2013) Enabling E-Services for Rural Community Through Union Information and Service Centers (UISCS), Journal of the Department of Government and Politics, 32, 49-57.

Marschollek, O., Beck, R. \& Gregory, R. (2010). Psychological contract violation in IT megaprojects in the context of public private partnership- The German TollCollect case. In Proceedings of the 18th European Conference on Information Systems.

Maskin, E. \& Tirole, J. (2008). Public-private partnerships and government spending limits. International Journal of Industrial Organization, 26(2), 412-420.

McConnell, S. (2001). Telecentres Around the World: Issues to be Considered and Lessons Learned, ICT Development Group, Richmond.

Misnikov, Y. (2003). How ICTs can serve good governance, How good governance can serve e-government and how regional cooperation can serve Information Society", LGI Journal, Budapest, Winter- 2003, pp.1723.

Moore M. \& Hartley J. (2008) Innovations in governance, Public Management Review, 10:1, 3-20, doi:10.1080/14719030701763161

Ng, S.T., Wong, Y.M.W. \& Wong, J.M.W. (2010). A structural equation model of feasibility evaluation and project success for public-private partnerships in Hong Kong. IEEE Transactions on Engineering Management, 57(2), 310-322.

Savas, E., S. (2000). Privatization and Public-Private Partnerships. New York: Chatham House.

Skelcher, C. (2007). Public private partnerships and hybridity. In The Oxford Handbook of Public Management, E. Ferlie, L.E. Lynn, \& C. Pollitt (Eds.) NY: Oxford University Press.

van Dijk, J., \& Hacker, K. (2003). The digital divide as a complex and dynamic phenomenon. The Information Society, 19(4), 315-326, doi:10.1080/01972240309487

Young, J., Ridley, G., \& Ridley, J. (2001). A preliminary evaluation of online access centres: Promoting micro e-business activity in small, isolated communities, The Electronic Journal on Information Systems in Developing Countries, 4. Available at http://www.is.cityu.edu.hk/ejisdc/vol4.htm

Warschauer, M. (2004). Technology and social inclusion: Rethinking the digital divide. Cambridge, Massachusetts: The MIT Press. 